\title{
USE OF THE TRANSCUTANEOUS ELECTRICAL NERVE STIMULATION (TENS) IN CONTROL OF NAUSEA AND VOMITING
}

Lindsay Pâmela UNTURA ${ }^{1}$

Melissa CIACCO ${ }^{2}$

Laura Ferreira de REZENDE ${ }^{3}$

1 Specialist in Oncology Physitherapy Pontifícia Universidade Católica (PUC Minas). Master in sustainable development and quality of life, São João da Boa Vista University Center of Associated Teaching Colleges, UNIFAE, São João da Boa Vista, SP, Brazil.

2 Specialist in Oncology Physitherapy Centro de Referência em Saúde da Mulher (CRSM)/ Faculdade de Ciências da Saúde de São Paulo (FACIS). Brazil.

3 Master and Doctor em gynecology and obstetrics in Universidade Estadual de Campinas (UNICAMP). Post-doc at Department of Obstetrics, Gynecol and Mastology by Universidade Estadua de Campinas (UNICAMP). Teacher of Physeotherapy course and teaching of Master course in susteinable development and quality of life of the universit center of FAE. Brazil.

Adress for correspondence: lindfisio@hotmail.com

Centro Universitário das Faculdades Associadas de São João da Boa Vista, UNIFAE

Praça Eng Paulo A Sandevile, 15. Bairro Santo André - São João da Boa Vista, SP, Brasil.

Clinical trial: protocol 482176. Approval date 15/12/2011.

Recebido em: 26/05/2014 - Aprovado em: 30/06/2014 - Disponibilizado em: 30/07/2014

Abstract

Nausea and vomiting are symptoms that cause significant impact on the quality of life cancer patients undergoing chemotherapy. The aim of this study was to evaluate the influence of TENS in controlling nausea and vomiting after chemotherapy. Methods: We performed an exploratory quantitative study of experimental blind randomized clinical trial with 83 patients with antineoplastic drugs classified as medium and high emetogenic degree. Were divided into two groups: in one group, classified as intervention, electro stimulation was performed with TENS for 30 minutes with a frequency of $10 \mathrm{~Hz}$ to $500 \mathrm{mS}$ pulse width with varying intensity, which was increased according to the tolerance of the patient from the point P6. In the other group, the control, patients suffered a simulation of electrical stimulation at zero frequency. Was performed electro stimulation during chemotherapy session. The symptoms and the amount of administered antiemetics at home were valued in the first two consecutive days of chemotherapy. The intensity of nausea was quantified by visual analog scale. The patient was instructed to write down the number of episodes of vomiting and antiemetic amount administered. Results: The average amount of nausea on the day of chemotherapy, vomiting on the day of chemotherapy and the next day following day and the amount of antiemetic taken at home in those first two days was significantly lower in the group of intervention. Conclusion: TENS showed a complementary effective in controlling nausea and vomiting.

Keywords: Cancer. Chemotherapy. TENS. Nausea. Vomiting.

Resumo

Náuseas e vômitos são sintomas que causam impacto significativo na qualidade de vida dos pacientes com câncer submetidos à quimioterapia . O objetivo deste estudo foi avaliar a influência do TENS no controle de náuseas e vômitos após a quimioterapia. Métodos: Foi realizada uma pesquisa quantitativa exploratória do tipo ensaio clínico randomizado cego com 83 pacientes com medicamentos antineoplásicos classificados como de médio e alto grau emetogênico . Foram divididos em dois grupos: em um grupo, classificado como intervenção, a eletroestimulação com TENS foi realizada por 30 minutos com uma frequência de $10 \mathrm{~Hz}$ a $500 \mathrm{mS}$ largura de pulso com intensidade variável, que foi aumentada de acordo com a tolerância do paciente sobre o ponto P6. No outro grupo, controle, os pacientes sofreram uma simulação da estimulação elétrica na frequiência zero. A electroestimulação foi realizada durante a sessão de quimioterapia. Os sintomas e a quantidade de antieméticos admisnistrados em casa foram avaliados nos dois primeiros dias consecutivos à quimioterapia. A intensidade de náusea foi quantificada pela escala analógica visual. O paciente foi orientado a anotar o 
número de episódios de vômitos e a quantidade de antiemético administrada. Resultados: A média da quantidade de náuseas no dia da quimioterapia, vômitos no dia da quimioterapia e no dia seguinte e da quantidade de antiemético tomadas em casa nesses dois primeiros dias foram significativamente menores no grupo da intervenção. Conclusão: A TENS mostrou-se um tratamento complementar eficaz no controle de náuseas e vômitos.

Palavras-chave: Câncer. Quimioterapia. TENS. Náuseas. Vômitos.

\section{Introduction}

Chemotherapy is a systemic treatment seeking the destruction of cancer cells, preventing them from growing and multiplying (Caseiro, 1997). However, can also affect healthy cells in the body, like the stomach cells, when these damaged cells send signals to brain, initiating the process of vomiting. There are antineoplastic drugs that cause more nausea and vomiting than others due to their degree of cytotoxicity, being classified as high, medium and low power emetogenic. (Baracat et al; 2000) About 70 to $80 \%$ of patients undergoing chemotherapy, exhibit these symptoms (Roscoe e Matterson, 2002), which are considered factor contributor to the abandonment of potentially curative treatment (Giglio, 1998).

Due to the high incidence of these complications after chemotherapy, different pharmacological approaches have been investigated in an attempt to minimize them. However, concerns about the side effects associated with traditional antiemetic and the high cost of the newer drugs have increased interest in the use of non-pharmacologic techniques such as transcutaneous electrical nerve stimulation (TENS).
TENS is a non-pharmacological techiniques predominantly used for symptomatic relief of pain, in order to influence and modulate the process of nerve conduction of pain and act on the release of endogenous opioids by exciting nerve fibers (Nelson et al 2003), and little explored as a resource not analgesic, besides being a cheap resource and free of side effects. The challenge of this study was to determine the influence of the use of TENS in patients with nausea and vomiting after chemotherapy.

\section{Subjects and Methods}

A blinded randomized controlled trial study with 83 patients, divided into two groups. In the group number one, electrical stimulation was performed with TENS for 30 minutes with frequency $10 \mathrm{~Hz}, 500$ microsecond pulse duration, to varying degrees as tolerated in 42 patients. In the group number two, consisting of 41 patients, there was a simulation of TENS stimulation at zero frequency. The apparatus used in this study was TENS KW Master Line ().

In both groups, one electrode was placed on the P6 point (located from placing three fingers above the patient's wrist (Heazel et al., 
2006; Vickers, 1996) as shown in Figure 1. The other electrode was placed at a point distal to P6 on the path corresponding to the innervations of the median nerve.

FIGURE 1 - Location of the P6

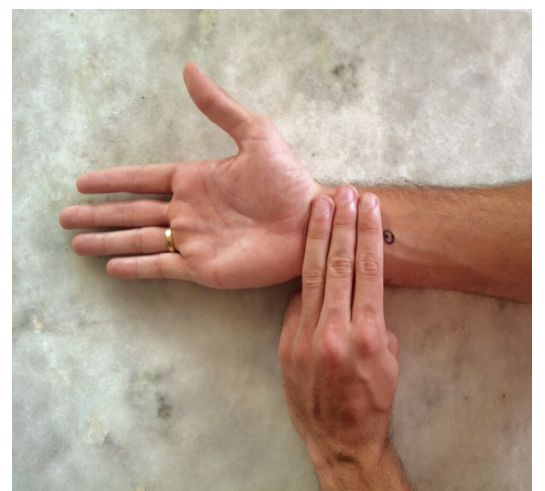

Source: Prepared by the author, 2012

The prescription of antiemetic was homogeneous; all patients used regular and controlled antiemetic Zofran ${ }^{\circledR}$ and Decadron ${ }^{\circledR}$ before infusion of chemotherapy drugs. The study included patients undergoing chemotherapy with antineoplastic drugs classified as medium and high emetogenic degree, who had performed at least one cycle of chemotherapy and were reported to have had nausea and / or vomiting as a side effect in the first 48 hours after the session. Patients unable to respond to questionnaires and failure to report the frequency of nausea and / or vomiting were excluded from this study.

All patients were submitted to a single TENS intervention at the time of chemotherapy. Symptoms nausea and vomiting, and the amount of antiemetic administered at home by the patient were evaluated on the day and the next day after the chemotherapy session by completing a form delivered to the patient at the time of application of TENS. The intensity of nausea were evaluated by a visual analog scale with score of zero to ten, with zero $(0)$ no nausea and/or vomiting ten (10) most intense nausea and/or vomiting were evaluated by the number of episodes per day, and the use of antiemetic was evaluated by the amount administered at home during that period. The patient did not receive medical guidance for use of antiemetic drugs in his home. The use of antiemetic Zofran ${ }^{\circledR}$ and Decadron ${ }^{\circledR}$ should only be done under necessity emetic.

Patients participated only after signing a Letter of Consent based on Resolution 466/12 (BRASIL, 1996). This study was approved by the Ethics Committee of the University Center of Associated Teaching Colleges-FAE, São João da Boa Vista, São Paulo, Brazil, under protocol number 482176 .

Data analysis the significance level adopted in the entire study was 5\% and $95 \%$ test power reliability. The data were entered into Excel with Integrated Action 2.3 software for statistical analysis. We used the t-Student test for independent samples and Pearson's correlation coefficient to evaluate the linear association between the variables.

\section{Results}

Table 1 shows the average age of patients and the average cycle of chemotherapy were 
during the study, homogeneous between groups. The same type of degree and sex of emetogenic chemotherapy drug used were also homogeneous between groups $(p>0.05)$.

TABLE 1 - Distribution of patients according to some control variables

\begin{tabular}{|c|c|c|c|c|c|}
\hline & \multicolumn{4}{|c|}{ IG CG } & \multirow[t]{2}{*}{$\mathrm{p}$-value } \\
\hline & Average & SD & Average & SD & \\
\hline Age & 53,2 & $( \pm 13,5)$ & 58,7 & $( \pm 13,2)$ & 0,06 \\
\hline $\begin{array}{l}\text { Chemo } \\
\text { cycle }\end{array}$ & 4,3 & $( \pm 4,1)$ & 3,7 & $( \pm 1,7)$ & 0,39 \\
\hline $\begin{array}{l}\text { IC: Inte } \\
\text { Chemo: } \\
\text { Statistic }\end{array}$ & $\begin{array}{l}\text { Cvention } \\
\text { Chemothe } \\
\text { al test: } \mathrm{t}-\mathrm{S}\end{array}$ & $\begin{array}{l}\text { roup } \\
\text { rapy } \\
\text { tudent }\end{array}$ & $\begin{array}{l}\text { CG:Co } \\
\text { SD: } \mathrm{St}\end{array}$ & $\begin{array}{l}\text { atrol Grou } \\
\text { andard dev }\end{array}$ & fiation \\
\hline
\end{tabular}

Table 2 shows the average intensity of nausea, vomiting frequency and amount of use of antiemetic medications domiciliary in the first two days after the use of TENS. The average day in the chemotherapy nausea, vomiting and the amount of antiemetic taken on the day and the next session of chemotherapy was significantly lower in the intervention group.

TABLE 2 - Intensity of nausea, vomiting frequency and amount of antiemetic domiciliary administered according to the group electrostimulation

\begin{tabular}{|c|c|c|c|c|c|}
\hline & IG & & $\mathrm{CG}$ & & $p$-value \\
\hline & Average & SD & Average & SD & \\
\hline \multicolumn{6}{|l|}{ Nausea } \\
\hline $\begin{array}{l}\text { Day of } \\
\text { chemo }\end{array}$ & 1,4 & $( \pm 2,8)$ & 3,8 & $( \pm 3,6)$ & $0,001 *$ \\
\hline Day after & 2,0 & $( \pm 3,2)$ & 3,3 & $( \pm 3,9)$ & 0,09 \\
\hline Vomiting & & & & & \\
\hline
\end{tabular}

$\begin{array}{llllll}\begin{array}{l}\text { Day of } \\ \text { chemo }\end{array} & 0,09 & ( \pm 0,4) & 1,1 & ( \pm 1,6) & 0,000 * \\ \text { Day after } & 0,35 & ( \pm 1,1) & 1,4 & ( \pm 1,7) & 0,000 *\end{array}$

\section{Antiemetic}

at home

Day $\quad 0,80 \quad( \pm 1,0) \quad 1,5 \quad( \pm 1,3) \quad 0,007 *$

of chemo

Day after $\quad 0,8 \quad( \pm 1,2) \quad 1,8 \quad( \pm 1,3) \quad 0,000 *$

SD: Standard deviation, $\quad *$ : Significant values for 95\% confidence

Statistical Test: Student's t-test p: p-value

IG: Intervention Group $\quad$ CG: Control Group

Chemo: Chemotherapy

\section{DISCUSSION}

This study evaluated the influence of electrical stimulation in cancer patients complaining of nausea and / or vomiting caused by chemotherapy. The average intensity of nausea on the day of chemotherapy, the occurrence of vomiting, and the amount of antiemetic drugs taken at home in the day and the day after chemo session was significantly lower in the intervention group. . Ozgur et al. (2001) used TENS associated with antiemetic drug ondansetron in 25 patients undergoing chemotherapy and observed a reduction in nausea and vomiting. These results corroborate the results found in this study, since the patients in the group of electrical stimulation had significant symptom reduction when compared to the control group. It is possible to observe that the improvement of 
nausea was significant on day of chemo treatment $(\mathrm{p}=0.001)$, confirming the results observed in a study Treish et al. (2003), suggesting that TENS has a greater effect on the reduction of acute nausea.

It is not known duration of antiemetic effect after stimulation of P6 point. Fassoulaki et al. (1993) observed that the most significant improvement lasted up to six hours after electrostimulation. Dundee et al. (1991) suggest that TENS may extend those effects suggesting more studies in this direction. This may explain why the TENS has not presented significant improvement in reducing nausea the day after electrical stimulation $(p=0.09)$ but the day of chemotherapy session.

The mechanism of action by which electrical stimulation reduces the incidence of nausea and

vomiting is not well understood. Neurophysiological studies suggest that stimulation

peripheral neuronal or by invasive needle (with manual stimulation, electrical, or injection point) or noninvasive (digital acupressure and TENS) promote changes in functions

sensory, motor and autonomic, visceral, hormonal, immune and brain, with results therapeutic ( Filshie, 1998).

Streitberger et al. (2006) propose some mechanisms by which stimulation of the P6 point reduce the frequency of nausea and vomiting. One mechanism is P6 is operated by neurotransmitters: studies have shown that stimulation influences this point the system of endogenous opioids such as serotonin transmission via activation of the fibers neuroadrenergic, serotonergic and are therefore involved in controlling these symptoms. Another mechanism suggests a direct effect on the smooth muscle of the intestine reducing tachyarrhythmia and thus suppressing gastric peristalsis backward movements and thus episodes of vomiting.

For Enest (2006) skin stimulation at low frequencies activate the fibers alpha and beta responsible for transmitting the sensation of touch, thus influencing neurotransmitters and promoting, consequently, inhibition of gastric acid secretion and standardization of gastric operation.

The neurotransmitters possibly involved would be the gastric inhibitory peptide (GIP) and vasoactive inhibitory peptide (VIP). The GIP is a potent inhibitor of gastric acid secretion whereas VIP acts as a neurotransmitter in motor neurons- the making relaxation ahead of the peristaltic wave and relaxation of sphincters, and secreting neurons - Inhibiting gastric acid secretion by the parietal cells, while promoting effect vasodilator (Polak, 1993).

Electrical stimulation is cheap, easy to use, free of side effects and effective in 
controlling symptoms of nausea and vomiting, pregnancy: A randomized control trial. since the intervention group had fewer American Journal of Obstetrics and complaints of symptoms. The use of TENS is a Gynecology . p.815-20, 2006.

promising feature supplement in the treatment of nausea and / or vomiting after chemotherapy. Further studies are needed be performed to investigate the action of TENS for a period exceeding 48 hours, and the pursuit of

7 Vickers J. Can acupuncture have specific effects on health? A systematic review of acupuncture antiemesis trials. Journal of the Royal Society of Medicine. p.303-11, 2006. parameters that can bring long-term results.

\section{References}

8 Brasil. Ministério da Saúde. Conselho 1 Caseiro, A . Caderno de Oncologia. 13 pesquisa envolvendo seres humanos. Inf. edição. Novartins; 1997.

Epidem. SUS:1996.

2 Baracat F, Fernandes H, Silva M. 9 Ozgur T, Sandikey Z, Uyugur M, Arik A. Cancerologia atual: um enfoque Combination of transcutaneous electrical multidisciplinar. São Paulo: Roca; 2000. stimulation nerve and ondasetron prevention cisplatin-induced emesis. Urology int.

3 Roscoe J, Matterson S. Acupressure and v.67.n.1.p.57-8, 2001.

acustimulation bands for control of nausea: a brief review. Am J Obstet Gynecol. v.185.p. 244-7, 2002.

10 Treish I, Shord S, Valgus J, Harvey D, Nagy J, Stegal, J et al. Randomized double-blind study of the Reliefband as an adjunct to standard 4 Giglio AMA. Novos avanços no controle de antiemetics in patients receiving moderately-high náusea pós quimioterapia antineoplásica. Rev. to highly emetogenic chemotherapy. Support Bras. Mastol. v.8.p. 196-204,1998.

Care Cancer. v. 11.n.8 p.516-21, 2003.

5 Nelson M, Hayes W, Currier P. Eletroterapia Clínica. São Paulo: Manole. 2003.

6 Heazel, A, Thorneycroft, J, Walton, V, Etherington, I. Acupressure for the in-patient treatment of nausea and vomiting in early
11 Fassoulaki A, Papilas K, Sarantoupolos C. Transcutaneous Electrical Nerve Stimulation Reduces the Incidence of Vomiting After Hysterectomy. Anesthesiology Analg. v.76.p.1012-4, 1993. 
12 Dundee J, Yang J, Mc-Millan C. Noninvasive stimulation of the P6 (Neiguan) antiemetic acupuncture point in cancer chemotherapy. Journal Royal Soc Med. v.84.p.210-2, 1991.

13 Filshie J, White A. Org Medical Acupuncture - a Western Scientific Approach, 1998.

14 Streitberger K, Ezzo J, Schneider A. Acupuncture for nausea and vomiting: an update of clinical and experimental studies. Elsevier. Autonomic Neuroscience. P 107-17, 2006.

15 Enest E. Acupuncture- a critical analisys. Journal of Internal Medicine.p.125-37, 2006.

16 Polak J. Hormônios gastrintestinais. In: Dani, R.; Castro L. Gastrointerologia clínica. $3^{\mathrm{a}}$. ed. Rio de Janeiro: Guanabara Koogan .p. 11072015, 1993. 